\title{
The Mediating Role of Person-organization fit on the Effect of Leader Support and Social Support on Job Satisfaction in Nurses ${ }^{1}$
}

(Research Article)

Hemşirelerde Lider Desteği ve Sosyal Desteğin Işs Tatminine Etkisinde KişiÖrgüt Uyumunun Aracılık Rolü

Doi: 10.29023/alanyaakademik.709919

İran AKKOÇ

Doç. Dr.,

dr.irfanakkoc@gmail.com

Orcid No: 0000-0002-5653-0508

Aysun TÜRE

Dr. Öğretim Üyesi, Eskişehir Osmangazi Üniversitesi Să̆lık Bilimleri Fakültesi Hemşirelik Bölümü

ature@ogu.edu.tr

Orcid No: 0000-0003-2513-0904

How to cite this article: Akkoç I. \& Türe, A. (2020). The Mediating Role of Person-organization fit on the Effect of Leader Support and Social Support on Job Satisfaction in Nurses. Alanya Academic Review, 4(3), Sayfa No.561-576.

\section{Keywords}

Leader Support, Social Support, Job Satisfaction, Person-organization Fit

Received: 26.03 .2020 Accepted: 02.09.2020

\begin{abstract}
The aim of this study was to investigate the mediating role of personorganization fit in the effect of social support and leader support on the job satisfaction of the nurses. The nurses $(N=550)$ working in a university hospital in the province of Eskişehir composed the sample. In this study, the relationships between the variables in the study were determined by analzing the data collected from 421 nurses by using the questionnaire form. The relationships between the variables of the study were analyzed by statistical methods such as factor analysis, correlation analysis, regression analysis, and Sobel tests. In conclusion, it was determined that personorganization fit had a partial mediating role on the effect of leader support on job satisfaction while it had a full mediating role on the effect of social support effect on job satisfaction.
\end{abstract}

\footnotetext{
${ }^{1}$ Ethical approval was obtained from the Non-Interventional Clinical Research Ethics Committee of Istanbul Medipol University (approval number: 10840098-604.01.01-E.8219, date of approval: 27/02/2019) . In addition, permission of the institution where the study was conducted were obtained.
} 


\section{INTRODUCTION}

Human is a social and emotional species. Therefore, individuals' business lives affect their private lives while their business lives also affect their private lives. Nowadays, organizations attach importance to ensuring their employees' job satisfaction to survive and to compete with other organizations. The advantage in the advancing competitive environment depends on the levels of harmony and coordination of the people involved in various organizational and managerial processes; this fact demonstrates the importance of ensuring the effective and productive compatibility of human resources to organizations, jobs and each other. Numerous variables play a role in the success of organizations. Job satisfaction definitely takes an important place among these variables. Numerous studies have been conducted by theorists and researchers to identify the variables affecting the job satisfaction of employees. One of the most studied variables is job satisfaction because job satisfaction is one of the most important variables that play a critical role in obtaining effectiveness and efficiency for organizations and employees.

Job satisfaction can be defined as the degree of positive emotion of the employee towards the job or the subjects related to the job (Adams and Bond, 2000). Job satisfaction is an important concept that enables individuals to be happy, successful and productive and canalized to work. Job satisfaction has great importance especially in the members of some occupational groups whose daily lives are directly affected by their professional lives and who need to be devoted. The employees with high job satisfaction levels had higher work motivation and provided better care services (Çam and Yıldırım, 2010). The job satisfaction of nurses is an important parameter in evaluating the quality of medical care in a hospital. When considering the positive effect of nurses' job satisfaction on the duration of hospital stay, infection rate, performance improvement in the institution where they work, every application that increases job satisfaction gains importance (Finn 2001). Heavy workload and poor working conditions negatively affect nurses' job satisfaction levels (Rafferty et al. 2007; Javasuriyar et al. 2012). Job satisfaction has a significant impact on essential organizational outcomes such as patient care quality (Kwak et al., 2010; Boamah et al., 2018).

In this context, a literature review about the variables that increase the job satisfaction of nurses was made. As a result of this review; leader support (Podsakoff et al., 1996; Netemeyer et al., 1997; Currivan, 1999; Gleason-Wynn and Mindel, 1999; Seo et al., 2004; Chen et al., 2012; Gillette et al., 2013; Gillette et al., 2018), social support (Cortese et al., 2010; Kwak et al., 2010; Hamaideh, 2011; Moura et al., 2014; Orgambídez-Ramos et al., 2014; Moneke and Umeh, 2015; Pohl and Galleta, 2017) and person-organization fit (Schneider et al., 1995; Kristof, 1996; Kristof-Brown et al., 2005; Vilela et al., 2008; Song and Chathoth, 2011; Astuti, 2010; Hunt, 2014; Chen et al., 2016; Zhang et al., 2017) were found to be in a significant relationship with job satisfaction. In this context, this research model was created in to analyze the relationships between the variables of leader support, social support, person-organization fit, and job satisfaction in terms of nursing. It is thought that the four variables included in this study provide significant benefits for the effectiveness and efficiency of nurses in their profession. In the literature review, we did not find any study on all of the variables included in this study. Therefore, it is suggested that it will contribute to the literature, new knowledge will be added to the scientific knowledge on the relationships between these variables and it will contribute to the generalizability of the knowledge related to these relations. 
In the context of this literature and approach, leader support, social support and personorganization fit variables which were thought to be related to nurses' job satisfaction, were examined. Leader support and social support are two variables that were suggested to have an impact on ensuring job satisfaction. The person-organization fit variable, which is a variable that can support the effect of leader support and social support on the job satisfaction of the employees, was also included in the study. Several recommendations were made to the managers and researchers within the scope of the results of this study.

\section{THEORY and HYPOTHESES}

\subsection{The Relationship between Leader Support and Job Satisfaction}

Job satisfaction includes emotional (personal feelings about own work) and cognitive (cognitive assessment of work) components (Fisher, 2000; Judge and Kammeyer-Mueller, 2012). Leader support makes an important contribution to employees' attitudes and behaviors. It provides the improvement of employees' perceptions towards the organization (De Coninck and Johnson, 2009). When job satisfaction is discussed as an emotional response of employees to their jobs, leader support has an important role in the effects that trigger this reaction.

Leaders are often capable of reducing the impact of negative emotional events on workers. The actions of the leaders (compliments, criticism, joy or frustration expressions and extra labor demands) are often important emotional events for their employees. Supportive leadership practices ensure that leaders feel that they are on the side of employees and have a positive attitude (Eisenberger et al., 2002; Allen et al., 2003; Ilies et al., 2007; Liao and Chuang, 2007; Kauppila, 2016). According to the studies in the literature, leader support increased job satisfaction ( Podsakoff et al., 1996; Netemeyer et al., 1997; Currivan, 1999; Gleason-Wynn and Mindel, 1999; Seo et al., 2004).

Leadership in nursing is important to create a quality job environment, to apply new care models, to increase labor force, and to ensure employee and patient satisfaction. In the studies on nurses, it was found that job the satisfaction levels of the nurses were high when they received high-level support from their leaders (Galletta et al., 2011; Chen et al., 2012; Gillette et al., 2013; Gillette et al., 2018). In this context, hypothesis 1 was developed based on theoretical and empirical studies.

Hypothesis 1: Leader support positively and significantly affects the job satisfaction of nurses.

\subsection{The Relationship between Social Support and Job Satisfaction}

Social support is an organizational variable that greatly affects the job satisfaction of nurses and job satisfaction affects the performance of nurses and the quality of health services (Chien and Yick, 2016). Ensuring a good job environment, effective leadership, and organizational support are important to improve job satisfaction (Copanitsanou et al., 2017; Al Hamdan et al., 2017).

Giving information and advice on how to do the job, ensuring effective communication within the team, giving feedback and recommendations by managers increase the social support perceptions of nurses. In the studies on nurses, it was found that social support provided by the managers and colleagues was an important determinant in increasing the job satisfaction of the nurses (Cortese et al., 2010; Kwak et al., 2010; Hamaideh, 2011; Moura et 
al. ., 2014; Orgambídez-Ramos et al., 2014; Moneke and Umeh, 2015; Pohl and Galleta, 2017). In this context, hypothesis 2 was developed based on theoretical and empirical studies.

Hypothesis 2: Social support positively and significantly affects the job satisfaction of nurses.

\subsection{The Relationship between Leader Support and Person-Organization Fit}

Individuals need to be supported by their managers to ensure their development and motivation (Hobfoll, 1989). Therefore, leader support is expected to moderate the relationship. In the literature, it was found that the leader support positively affected the person-organization fit in the nurses (Huang et al., 2005; Hunt, 2014; Fan, 2018). In this context, hypothesis 3 was developed based on the theory and empirical studies.

Hypothesis 3: Leader support positively and significantly affects person-organization fit.

\subsection{The Relationship between Social Support and Person-Organization Fit}

Strong business friendships and social interactions reduce the adverse effects in job environment and provide high job satisfaction (Tourangeau et al., 2010). The positive effects of the organizational and social support provided by the nurse leaders on the working life were determined (Laschinger et al., 2006; Kath et al., 2012; Fan, 2018). There was no study investigating the relationship between social support and person-organization fit. However, hypothesis 4 was developed because there may be a significant relationship between social support and person-organization fit according to the literature.

Hypothesis 4: Social support positively and significantly affects person-organization fit.

\subsection{The Relationship between Person-Organization Fit and Job Satisfaction}

It is widely accepted in the literature that organizational resources and expectations of employees determine job satisfaction (Farrell and Rusbult, 1981). In this respect, the most important determinant of job satisfaction is person-organization fit. The studies on job satisfaction and person-organization fit determined that there was a relationship between these two variables. (Schneider et al., 1995; Kristof, 1996; Netemeyer et al., 1997; KristofBrown et al., 2005; Vilela et al., 2008; Song and Chathoth, 2011). In the literature, there was a significant relationship between job satisfaction and person-organization fit in the studies conducted with nurses (Astuti, 2010; Hunt, 2014; Chen et al., 2016; Zhang et al., 2017). In this context, hypothesis 5 was developed from the theory and empirical studies.

Hypothesis 5: Person-organization fit positively and significantly affects the job satisfaction of nurses.

\subsection{The Mediating Role of Person-Organization Fit}

In the literature, there were relationships between leader support and job satisfaction (Galletta et al., 2011; Chen et al., 2012; Gillette et al., 2013; Hunt, 2014; Gillette et al., 2018) and between leader support and person-organization fit (Huang et al., 2005; Hunt, 2014). In the studies, it was also found that there was a relationship between person-organization fit and job satisfaction (Verplanken, 2004; Meyer et al., 2010; Risman et al., 2016). The significant relationships between these three variables provide strong arguments for the mediating role of person-organization fit. In this context, hypothesis 7 was developed based on empirical studies.

Hypothesis 6: There is an mediating role of person-organization fit in the effect of leader support on job satisfaction. 
In the studies, the positive correlations were found between social support and job satisfaction (Cortese et al., 2010; Kwak et al., 2010; Hamaideh, 2011; Moura et al., 2014; OrgambídezRamos et al., 2014; Moneke and Umeh, 2015; Pohl and Galleta, 2017) and between social support and person-organization fit. There was also a relationship between personorganization fit and job satisfaction (Verplanken, 2004; Meyer et al., 2010; Chen et al., 2016; Risman et al., 2016; Zhang et al., 2017). The significant relationships between these three variables provide strong pieces of evidence for the mediating role of person-organization fit. In this context, hypothesis 6 was developed based on the results of the empirical studies.

Hypothesis 7: Person-organization fit has an mediating role in the effect of social support on job satisfaction.

The research model and hypotheses which were developed from the theory and studies are presented in Figure 1.

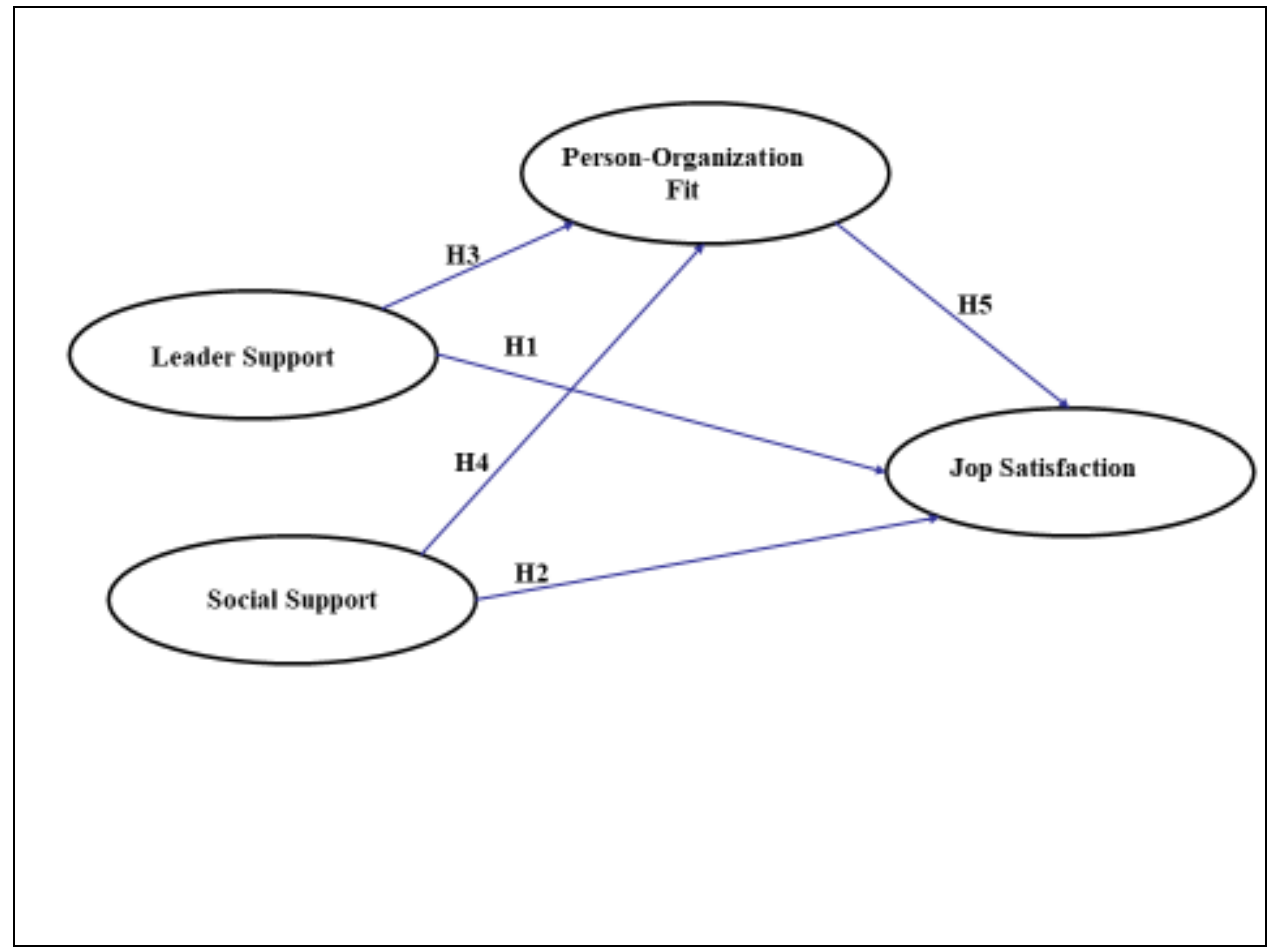

Figure 1. Research Model and Hypotheses

\section{METHOD}

\subsection{Objective and Type of the Study}

This study was conducted as a descriptive study to investigate the mediating role of personorganization fit in the effect of perceived social support and leader support on job satisfaction of the nurses. 


\subsection{Universe and Sample of the Study}

The study was conducted with a sample of the nurses working in a university hospital in the city center of Eskişehir province. The universe of the study consisted of the nurses working in the university hospital (N:550). The sample of the study consisted of 421 nurses working at this institution at the time of the study. The sample size was calculated as 226 people by taking into account a 5\% error margin with a 95\% confidence interval (Sekaran, 1992). In this context, 525 participants who were randomly selected using the cluster sampling method, filled the questionnaire. 467 of the questionnaire forms were brought back from the participants while 421 of them were found to be suitable for analysis.

\subsection{Data Collection Tools}

The data were collected by interviewing the nurses who agreed to participate in the study. The researchers used the Personal Information Form, Leader Support Scale, Social Support Scale, Person-Organization Fit Scale, and Job Satisfaction Scale as data collection tools.

Personal Information Form: The questionnaire consisted of 6 questions including sociodemographic and working life characteristics such as age, gender, marital status, educational status, the duration of professional experience, and the position of the nurses included in the study.

Leader Support Scale: To measure the leader support which was perceived by the employees, a 5-item scale of Netemeyer et al. (1997) was used. It was previously used by Ackfeldt and Coote (2005). The Turkish validity reliability analysis of the scale was performed by Akkoç et al. (2011). The Cronbach's Alpha reliability coefficient of the whole scale was determined as $\alpha=0.92$ (Akkoç et al., 2011). The scale items are scored using a 5-point Likert system from 1 (strongly disagree) to 5 (strongly agree).

In this study, exploratory factor analysis was firstly performed to test the structural validity of the LS scale. As a result of the analysis, it was determined that the data fit the single factor structure of the scale and the factor loadings of the scale ranged from 0.72 to 0.93 . The result of the KMO analysis of the scale was 0.86 while the result of the Barlett test was statistically significant $(\mathrm{p}=0.000)$. After these analyses, the CFA was performed with the AMOS package program. As a result of the factor analysis, it was determined that the data fit the single factor structure of the scale; the factor loads ranged between 0.72 and 0.96 . The values of the goodness of fit of the scale are at acceptable standards (Table 1). As a result of the reliability analysis, the Cronbach Alpha's coefficient of the scale was found as $\alpha=0.93$.

Social Support Scale: The 4-item scale developed by Totterdell and Holman (1998) and used by Chen et al. (2009) was used to determine the level of social support perceived by the employees. The Cronbach's Alpha reliability coefficient of the whole scale was found to be above $\alpha=0,80$ (Chen et al., 2009). The scale items were scored using a 5-point Likert system, from 1 (strongly disagree) to 5 (strongly agree).

In this study, exploratory factor analysis was firstly performed to test the structural validity of the social support scale. As a result of the analysis, it was determined that the data fit the single factor structure of the scale. The factor loads of the 4-item scale ranged between 0.63 and 0.85 . The result of the KMO analysis of the scale was 0.79; the result of the Barlett test was significant $(\mathrm{p}=0.000)$. After these analyses, the CFA was performed with the AMOS package program. As a result of factor analysis, it was determined that the data fit the single factor structure of the scale; the factor loads ranged from 0.57 to 0.88 . The goodness of fit of 
the scale was at acceptable standards (Table 1). As a result of the reliability analysis, the Cronbach's Alpha coefficient of the scale was found to be $\alpha=0.84$.

Person-Organization Fit Scale: The 4-item scale was developed by Netemeyer et al. while the Turkish validity reliability analysis of the scale was performed by Turunç et al. (2013). The Cronbach's Alpha reliability coefficient of the whole scale was found to be $\alpha=0.74$ (Turunç et al., 2013). The items of the scale were scored by using a 5-point Likert system, from 1 (strongly disagree) to 5 (strongly agree).

To test the structural validity of the scale, exploratory factor analysis was performed at first. As a result of the analysis, it was observed that the data were fit the single factor structure of the scale. The factor loads of the 4-item scale ranged between 0.72 and 0.89 . The result of the $\mathrm{KMO}$ analysis was 0.82 and the result of the Barlett test was significant $(\mathrm{p}=.000)$. After these analyses, the CFA was performed with the AMOS package program. As a result of the factor analysis, it was determined that the data fit the single factor structure of the scale; the factor loads ranged between 0.69 and 0.79 . The goodness of fit of the scale was at acceptable standards (Table 1). As a result of the reliability analysis, the Cronbach's Alpha reliability coefficient of the scale was found as $\alpha=0.89$.

Job Satisfaction Scale: The 5-item scale which was developed by Chen et al. (2009) by giving reference to Arnett (1999) and Judge et al. (2009) to determine the level of job satisfaction of employees. The Turkish validity study of the scale was conducted by Akkoç and Turunç (2011). The Cronbach's Alpha reliability coefficient of the whole scale was $\alpha=0.81$. The scale items were scored using a 5-point Likert type system, from 1 (strongly disagree) to 5 (strongly agree).

To test the structural validity of the job satisfaction scale, exploratory factor analysis was performed at first. As a result of the analysis, it was determined that the data fit the single factor structure of the scale. The factor loads of the scale ranged between 0.42 and 0.89 . The result of the KMO analysis was 0.75 and the result of the Barlett test was significant $(\mathrm{p}=0.000)$. After these analyses, the CFA was conducted with the AMOS package program. The data fit the single factor structure of the scale and the factor loads ranged between 0.58 and 0.97. The goodness of fit of the scale was at acceptable standards (Table 1). As a result of the reliability analysis, the Cronbach Alpha's reliability coefficient of the scale was found as $\alpha=0.80$.

\subsection{Ethical Statement}

Ethical approval was obtained from the Non-Interventional Clinical Research Ethics Committee of Istanbul Medipol University (approval number: 10840098-604.01.01-E.8219, date of approval: 27//02/2019). In addition, permission of the institution where the study was conducted were obtained.

\subsection{Analysis of the Data}

The data were analyzed with the SPSS and AMOS programs. In this context, Confirmatory Factor Analysis (CFA) was applied to the scales used in the study. The relationships between the variables in the study were analyzed with statistical methods such as factor analysis, correlation analysis, regression analysis and sobel tests. 


\section{RESULTS}

$64.8 \%(n=273)$ of the participant nurses were women, $65.3 \%(n=275)$ of them were married; $52.5 \%(n=221)$ of them were university graduates. The mean age of the sample was 32.9 years; their mean number of working years was 7.5 years. $7.6 \%$ of the participant nurses worked in managerial positions.

The data were analyzed with the SPSS and AMOS programs. In this context, the CFA was performed for the scales in the study. The CFA results are presented in Table 1. It was determined that all variables had acceptable goodness of fit values.

Table 1. Goodness of Fit Values of the Scales as a Result of Confirmatory Factor Analysis

\begin{tabular}{|l|c|c|c|c|c|c|c|c|c|}
\hline \multicolumn{1}{|c|}{ Variables } & $\mathbf{X}^{2}$ & $\mathbf{D f}$ & $\begin{array}{c}\text { CMIN/ } \\
\mathbf{D F} \\
\mathbf{5}\end{array}$ & $\begin{array}{c}\text { GFI } \\
\mathbf{2 . 8 5}\end{array}$ & $\begin{array}{c}\text { AGFI } \\
\mathbf{2 . 8 0}\end{array}$ & $\begin{array}{c}\text { CFI } \\
\mathbf{2 . 9 0}\end{array}$ & $\begin{array}{c}\text { NFI } \\
\mathbf{2 . 9 0}\end{array}$ & $\begin{array}{c}\text { TLI } \\
\mathbf{2 . 9 0}\end{array}$ & $\begin{array}{c}\text { RMSEA } \\
\leq .08\end{array}$ \\
\hline Leader Support & 4.42 & 3 & 1.47 & 1 & .98 & 1 & 1 & 1 & .03 \\
\hline Social Support & 1.80 & 1 & 1.80 & 1 & .98 & 1 & 1 & .99 & 04 \\
\hline Person-Organization Fit & .90 & 1 & .90 & 1 & 1 & 1 & 1 & 1 & .00 \\
\hline Job Satisfaction & 7.22 & 3 & 2.40 & .99 & .97 & .99 & .99 & .98 & .06 \\
\hline
\end{tabular}

Note: The goodness of fit value intervals were determined according to acceptable standards.

In the second stage, the means, standard deviations and correlations between the perceived leader support, social support, person-organization fit and job satisfaction of the participants were analyzed. The results are presented in Table 2 . In the third stage of the analysis, the mediating effect was analyzed with three-stage hierarchical regression analysis proposed by Baron and Kenny (1986).

Table 2. Mean, Standard Deviation and Correlation Values for the Data

\begin{tabular}{|l|c|c|c|c|c|c|}
\hline & Mean & SD & $\mathbf{1}$ & $\mathbf{2}$ & $\mathbf{3}$ & $\mathbf{4}$ \\
\hline 1. Leader Support & 3.13 & .98 & $\mathbf{( . 9 3 )}$ & & & \\
\hline 2. Social Support & 3.45 & .77 & $.24 * *$ & $\mathbf{( . 8 4 )}$ & & \\
\hline 3. Person-Organization Fit & 3.40 & .85 & $.50 * *$ & $.56 * *$ & $\mathbf{( . 8 9 )}$ & \\
\hline 4. Job Satisfaction & 3.18 & .74 & $.59 * *$ & $.38^{* *}$ & $\mathbf{. 5 8 * *}$ & $\mathbf{( . 8 0 )}$ \\
\hline
\end{tabular}

Note: Cronbach's Alpha reliability coefficient are shown in brackets, ${ }^{*} p \leq .05 .{ }^{* *} p \leq 01$

As a result of the analyses, significant relationships were found between all dependent and independent variables included in the study (Table 2).

In the context of analysis, collinearity was also analyzed to determine whether there was a multilinear relation problem in the model. The obtained tolerance and VIF values confirmed the absence of multilinear relations between the independent variables (Tolerance>.2, $\mathrm{VIF}<5)$.

In order to explain the effect of leader support (LS) and social support (SS) on job satisfaction (JS) and the mediating role of person-organization fit (POF) in this effect, a three-stage regression analysis which was proposed by Baron and Kenny (1986) was performed. According to this method, the independent variable should have an effect on the dependent variable and the mediator. When the mediator is included in the regression analysis with the 
independent variable, the regression coefficient of the independent variable on the dependent variable should decrease, while the mediator variable should continue to have a significant effect on the dependent variable (JS). In this context, in order to determine the mediating role of social support, the relationships between the LS-SS-POF and JS were analyzed by hierarchical regression analyzes and Sobel tests. The findings of the mediation anaysis are sfhown in Table 3 and 4.

Within the scope of the mediation test, the relationship between leader support (LS) as the first independent variable and job satisfaction (JS) was analyzed. In the first step, it was found that LS significantly affected JS $(\beta=.60, \mathrm{p}<.001)$. In the second step, the effect of LS on POF was analyzed. As a result of the analysis, LS significantly affected POF $(\beta=.49, \mathrm{p}$ $<.001$ ). It was found that POF which was analyzed as a mediator significantly affected JS ( $\beta=$ $.57, \mathrm{p}<.001)$. In the last step, LS and POF were analyzed together; their effects on JS were analyzed. As a result of co-analysis of LD and POF, the effect of LD on JS continued and decreased $(\beta=.42, p<.001)$ while the effect of POF on JS continued $(\beta=.37, p<.001)$. After fulfilling these conditions, Sobel test was performed and Sobel $(\mathrm{z})$ was found as significant $(\mathrm{z}$ $=8.8, \mathrm{p}<.001)$. This finding showed that POD had a partial mediator role in the effect of LS on JS. As a result of this analysis, H1, H3, H5 and H6 (the mediating hypothesis) were found to be supported.

Table 3. Mediation Analysis Results

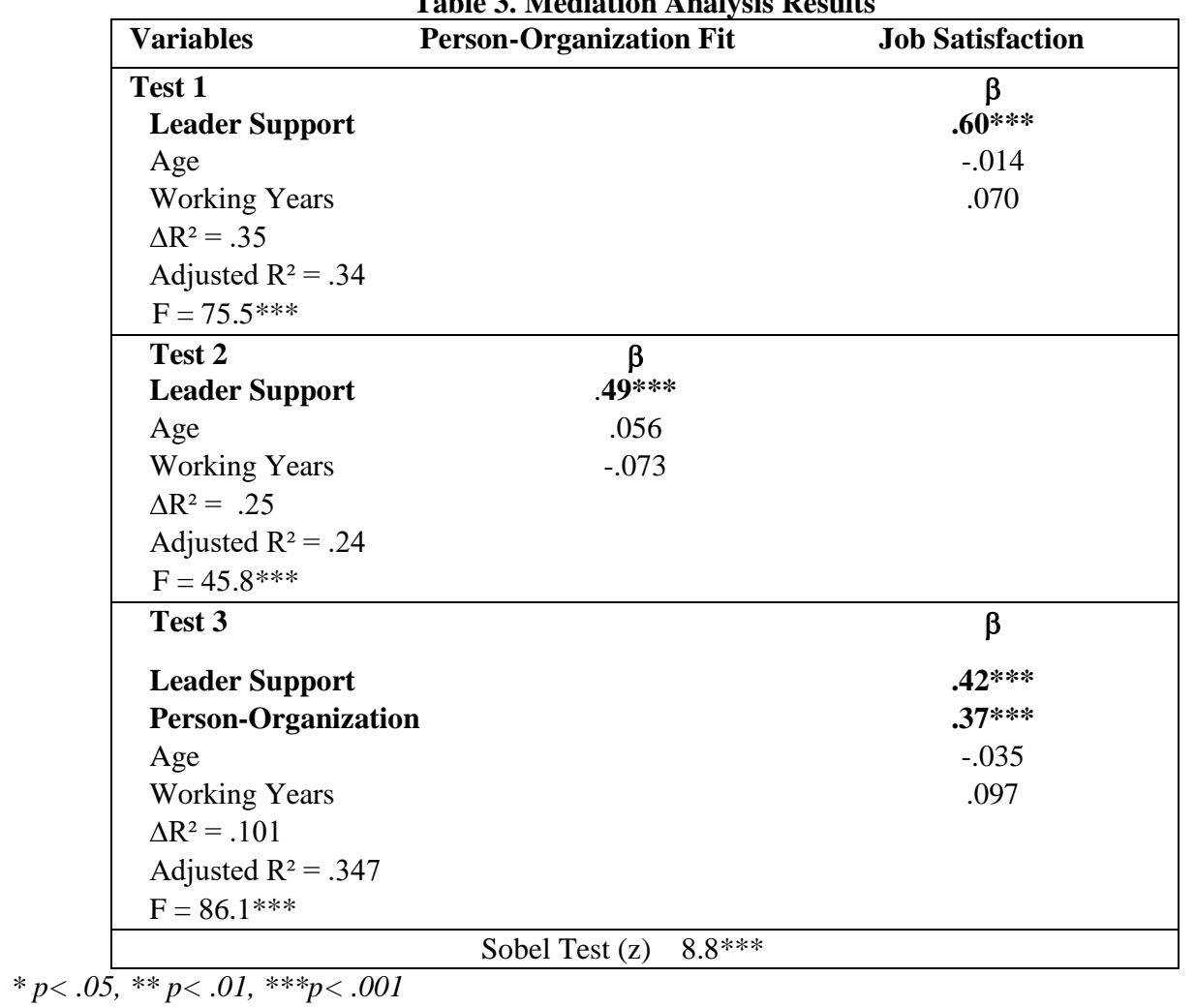

In the second part of the mediation analysis, the relationships between social support (SS) as the other independent variable and job satisfaction (JS) were analyzed. In the first step, it was found that SS had a significant effect on JS $(\beta=.37, \mathrm{p}<.001)$. In the second step, the effect 
of SS on POF was analyzed. As a result of the analysis, SS significantly affected POF ( $\beta=$ $.56, \mathrm{p}<.001)$. It was found that POF significantly affected JS $(\beta=.57, \mathrm{p}<.001)$. In the last step, SS and and POF were analyzed together; their effects on JS were analyzed. As a result of this analysis, the effect on SS was eliminated by the coanalysis of SS and POF $(\beta=.08, p>$ $.05)$; the effect of POF on JS continued $(\beta=.52, \mathrm{p}<.001)$. Sobel test was performed and Sobel $(\mathrm{z})$ was found as significant $(\mathrm{z}=9.8, \mathrm{p}<.001)$. This finding showed that SS had a fully mediator role in the effect of SS on JS. As a result of this analysis, H2, H4 and H7 (mediation hypothesis) were supported.

\begin{tabular}{|c|c|c|}
\hline Variables & Person-Organization Fit & Job Satisfaction \\
\hline $\begin{array}{l}\text { Test } 1 \\
\text { Social Support } \\
\text { Age } \\
\text { Working Years } \\
\Delta \mathrm{R}^{2}=.14 \\
\text { Adjusted } \mathrm{R}^{2}=.13 \\
\mathrm{~F}=23.0^{* * *}\end{array}$ & & $\begin{array}{c}\beta \\
.37 * * * \\
.056 \\
-.073\end{array}$ \\
\hline $\begin{array}{l}\text { Test } 2 \\
\text { Social Support } \\
\text { Age } \\
\text { Working Years } \\
\Delta \mathrm{R}^{2}=.33 \\
\text { Adjusted } \mathrm{R}^{2}=.32 \\
\mathrm{~F}=66.9^{* * *}\end{array}$ & $\begin{array}{c}\boldsymbol{\beta} \\
. \mathbf{5 6}^{* * * *} \\
.023 \\
-.114\end{array}$ & \\
\hline Test 3 & & $\beta$ \\
\hline $\begin{array}{l}\text { Social Support } \\
\text { Person-Organization Fit } \\
\text { Age } \\
\text { Working Years } \\
\Delta \mathrm{R}^{2}=.184 \\
\text { Adjusted } \mathrm{R}^{2}=.319 \\
\mathrm{~F}=113.3 * * *\end{array}$ & & $\begin{array}{c}. \mathbf{0 8} \\
. \mathbf{5 2} * * * \\
-.016 \\
.021\end{array}$ \\
\hline & Sobel Test (z) 9.8*** & \\
\hline
\end{tabular}

According to the results of the hierarchical regression analysis, it was determined that the person-organization fit increased the job satisfaction as the independent variables affected dependent variables (Table 3, 4).

\section{DISCUSSION AND CONCLUSION}

In this study, the effect of leader support and social support on job satisfaction and the mediating role of person-organization fit in this effect were investigated. The effects of the variables included in the analysis on job satisfaction were explained by hierarchical regression analysis. In this study, it was found explanatory findings about the relationship between the leader support, social support, job satisfaction and person-organization fit for the nurses.

It was determined that leader support was related to job satisfaction; it increased job satisfaction positively and significantly. This finding is consistent with similar studies 
(Podsakoff et al., 1996; Netemeyer et al., 1997; Currivan, 1999; Gleason-Wynn and Mindel, 1999; Seo et al. , 2004; Galletta et al., 2011; Chen et al., 2012; Gillette et al., 2013; Gillette et al., 2018). To create positive business manners in employees, it is important to have leaders and managers who care about the needs of employees and provide support to employees in the work environment (Ackfeldt and Coote, 2005). Leader support plays a critical role in creating positive business manners, particularly job satisfaction.

It was determined that social support was related to job satisfaction; it significantly increased job satisfaction. This result is consistent with similar studies (Cortese et al., 2010; Kwak et al., 2010; Hamaideh, 2011; Moura et al., 2014; Orgambídez-Ramos et al., 2014; Moneke and Umeh, 2015; Pohl and Galleta, 2017). Accordingly, social support perceived by nurses is an important variable that increases the job satisfaction of the nurses and makes contributions positively. Enhancing empowerment in a supportive environment enables job satisfaction of nurses.

It was determined that leader support was related to person-organization fit and positively and significantly increased person-organization fit. This finding is consistent with similar studies (Huang et al., 2005; Hunt, 2014; Fan, 2018). The responsibility of nurse leaders is to create a confident and safe nurse community (Eriksson, 2006). It is important that providing a supportive work environment for nurses by their leaders. To reduce the uncertainty and surprises experienced by nurses who are beginners, it is very important to provide adequate information by their leaders (Risman et al., 2016). It is known that leaders provide support for employees by their functions as focusing on the goals, adopting the vision, providing support and feedback functions (Ackfeldt and Coote, 2005; Podsakoff et al., 1996). In this context, perceived leader support positively contributes to person-organization fit by facilitating the compatibility of personal and organizational values, goals and needs in nurses.

It was found that social support was associated with person-organization fit and positively; it significantly increased person-organization fit. The perception of social support is especially effective in meeting the need for belonging and is very important for the employees to gain confidence in their working environments. Nurses who have a sense of belonging and trust can develop person-organization fit by adapting to organizational goals and values with their perception of social support.

It was determined that person-organization fit was related to job satisfaction; it significantly increased job satisfaction. This finding is consistent with similar studies (Astuti, 2010; Hunt, 2014; Chen et al., 2016; Zhang et al., 2017). The basic social needs of employees are love, self-confidence, sense of belonging, security, and recognition. The meeting of this kind of social needs plays a critical role by positively affecting the physical and mental health of employees. Therefore, the job satisfaction of nurses with positive social support perception is higher.

It was thought that perceived leader support and social support had an effect on the job satisfaction of the employees; this effect may be reflected on the output variables through some variables. As a result of this study, it was determined that person-organization fit had a partial mediation role in the effect of leader support on job satisfaction of nurses; personorganization fit had a full mediating role in the effect of social support on job satisfaction.

Nursing Implications: As a contribution of this study to the practice, it can be stated that leader support, social support, and person-organization fit are important in increasing the job satisfaction of nurses who have professional roles and responsibilities. If these three variables have a place in organizational culture, it may significantly contribute to job satisfaction. 
Ensuring job satisfaction of nurses is important for providing nursing care within the framework of professional standards and ethical principles, evidence-based planning and implementing of nursing care within the scope of the nursing diagnosis process, managing manpower resources and care environment, risk management, quality development, training, providing consultancy, and communication roles. The quality of care also has a significant effect on patient satisfaction and safety.

Firstly, the contribution of this study to the theory can be stated as the finding that the effect of leader-support and social support in organizations on job satisfaction can be increased by the mediating role of person-organization. Second, there was no study investigating the mediating effect of social support on the relationship between these two independent variables. This finding on the positive effect of person-organization fit on the increasing effect of leader support and social support on the job satisfaction of the nurses is highly valued as the first scientific evidence of the mediating role of person-organization fit. Lastly, this study determined that social support is associated with person-organization fit; the study also determined that it significantly increases person-organization fit for the first time in the literature.

It can be stated that the job satisfaction of nurses can be increased when leader support and social support are perceived by nurses and an important organizational attitude as personorganization fit is formed.

\section{REFERENCES}

ACKFELDT, A. L., \& COOTE, L. V. (2005). “A study of organizational citizenship behaviors in a retail setting", Journal of Business Research, 58(2): 151-159.

ADAMS, A., \& BOND, S. (2000). "Hospital nurses' job satisfaction, individual and organizational characteristics", Journal of Advanced Nursing, 32(3): 536-543.

AKKOÇ, İ., TURUNÇ, Ö, \& ÇALIŞKAN, A. (2011). "Gelişim kültürü ve lider desteğinin yenilikçi davranış ve iş performansına etkisi: İş-aile çatışmasının aracılık rolü”, ISGUC the Journal of Industrial Relations and Human Resources, 13(4): 83-114.

AL HAMDAN, Z., MANOJLOVICH, M., \& TANIMA, B. (2017). "Jordanian nursing work environments, intent to stay, and job satisfaction", Journal of Nursing Scholarship, 49(1): 103-110.

ALLEN, D. G., SHORE, L. M., \& GRIFFETH, R. W. (2003). "The role of perceived organizational support and supportive human resource practices in the turnover process", Journal of Management, 29(1): 99-118.

ARNETT, J.J. (1999), “Adolescent storm and stress, revisited”, American Psychologist, 54(5): 317-326

ASTUTI, S. D. (2010). "Model Person-Organization Fit (PO Fit Model) Terhadap Kepuasan Kerja, Komitmen Organisasional Dan Kinerja Karyawan", Jurnal Bisnis dan Ekonomi, 17(1): 43-60.

BARON, R. M. \& KENNY, D. A. (1986). "The Moderator-Mediator Variable Distinction in Social Psychological Research: Conceptual, Strategic and Tactical Considerations", Journal of Personality and Social Psychology, 51(6): 1173-1182. 
BOAMAH, S. A., LASCHINGER, H. K. S., WONG, C., \& CLARKE, S. (2018). "Effect of transformational leadership on job satisfaction and patient safety outcomes", Nursing Outlook, 66(2):180-189.

CHEN, C. K., LIN, C., WANG, S. H., \& HOU, T. H. (2009). “A study of job stress, stress coping strategies, and job satisfaction for nurses working in middle-level hospital operating rooms", Journal of Nursing Research,17(3):199-211.

CHEN, F. C., KU, E., SHYR, Y. H., CHEN, F. H., \& CHOU, S. S. (2009). "Job demand, emotional awareness, and job satisfaction in internships: The moderating effect of social support", Social Behavior and Personality: an International Journal,37(10):1429-1440.

CHEN, P., SPARROW, P., \& COOPER, C. (2016). "The relationship between personorganization fit and job satisfaction", Journal of Managerial Psychology, 31(5): 946959.

CHEN, W. T., \& YICK, S. Y. (2016). “An investigation of nurses' job satisfaction in a private hospital and its correlates", The Open Nursing Journal, 10(6): 99-112.

CHEN, Z., SUN, H., LAM, W., HU, Q., HUO, Y., \& ZHONG, J. A. (2012). “Chinese hotel employees in the smiling masks: Roles of job satisfaction, burnout, and supervisory support in relationships between emotional labor and performance", The International Journal of Human Resource Management, 23(4): 826-845.

COPANITSANOU, P., FOTOS, N., \& BROKALAKI, H. (2017). "Effects of work environment on patient and nurse outcomes", British Journal of Nursing, 26(3): 172176.

CORTESE, C. G., COLOMBO, L., \& GHISLIERI, C. (2010). “Determinants of nurses' job satisfaction: the role of work-family conflict, job demand, emotional charge and social support", Journal of Nursing Management, 18(1): 35-43.

CURRIVAN, D. B. (1999). "The causal order of job satisfaction and organizational commitment in models of employee turnover", Human Resource Management Review, 9(4): 495-524.

ÇAM, O. \& YILDIRIM, S. (2010). "Hemşirelerde iş doyumu ve etkileyen faktörler”, Türkiye Klinikleri, Journal of Nursing, 2(1): 64-70.

DE CONINCK, J. B., \& JOHNSON, J. T. (2009). "The effects of perceived supervisor support, perceived organizational support, and organizational justice on turnover among salespeople”, Journal of Personal Selling \& Sales Management, 29(4): 333350 .

EISENBERGER, R., STINGLHAMBER, F., VANDENBERGHE, C., SUCHARSKI, I. L., \& RHOADES, L. (2002). "Perceived supervisor support: Contributions to perceived organizational support and employee retention", Journal of Applied Psychology, 87(3): 565-573.

FAN, P. (2018). "Person-organization fit, work-family balance, and work attitude: The moderated mediating effect of supervisor support" , Social Behavior and Personality: an international journal, 46(6): 995-1010. 
FARRELL, D., \& RUSBULT, C. E. (1981). "Exchange variables as predictors of job satisfaction, job commitment, and turnover: The impact of rewards, costs, alternatives, and investments", Organizational Behavior and Human Performance, 28(1): 78-95.

FINN, C.P. (2001). "Autonomy: an important component for nurses", Job Satisfaction International Journal of Nursing Studies, 38(3): 349-357.

FISHER, C. D. (2000). "Mood and emotions while working: missing pieces of job satisfaction?", Journal of Organizational Behavior: The International Journal of Industrial, Occupational and Organizational Psychology and Behavior, 21(2): 185-202.

GAlletta, M., PORTOGHese, I., PENNA, M. P., BATtistelli, A., \& SAiAni, L. (2011). "Turnover intention among Italian nurses: The moderating roles of supervisor support and organizational support”, Nursing \& Health Sciences, 13(2): 184-191.

GILlet, N., COLOMBAT, P., MICHINOV, E., PRONOST, A. M., \& FOUQUEREAU, E. (2013). "Procedural justice, supervisor autonomy support, work satisfaction, organizational identification and job performance: The mediating role of need satisfaction and perceived organizational support", Journal of Advanced Nursing, 69(11): 2560-2571.

GILlET, N., FOUQUEREAU, E., COİLlOT, H., COUGOT, B., MORET, L., DUPONT, S., \& COLOMBAT, P. (2018). "The effects of work factors on nurses' job satisfaction, quality of care and turnover intentions in oncology", Journal of Advanced Nursing, 74(5): 1208-1219.

GLEASON-WYNN, P., \& MINDEL, C. H. (1999). “A proposed model for predicting job satisfaction among nursing home social workers", Journal of Gerontological Social Work, 32(3): 65-79.

HAMAIDEH, S. H. (2011). "Burnout, social support, and job satisfaction among Jordanian mental health nurses", Issues in Mental Health Nursing, 32(4): 234-242.

HOBFOLL, S.E. (1989). "Conservation of resources: A new attempt at conceptualizing stress", American Psychologist, 44: 513-524.

HUANG, M. P., CHENG, B. S., \& CHOU, L. F. (2005). "Fitting in organizational values: The mediating role of person-organization fit between CEO charismatic leadership and employee outcomes", International Journal of Manpower, 26(1): 35-49.

HUNT, D. (2014). "Does value congruence between nurses and supervisors effect job satisfaction and turnover?" Journal of Nursing Management, 22(5): 572-582.

ILIES, R., NAHRGANG, J. D., \& MORGESON, F. P. (2007). "Leader-member exchange and citizenship behaviors: A meta-analysis", Journal of Applied Psychology, 92(1): 269.

JAYASURIYAR, R., WHITTAKER, M., HALIM, G. \& MATINEAU, T. (2012). "Rural health workers and their work environment the role at inter personel factors on job satisfaction of nurses in rural paua New Guinea", Biomedcentral Health Services Research, 12(6): 156.

JUDGE, T. A., \& KAMMEYER-MUELLER, J. D. (2012). "Job attitudes", Annual Review of Psychology, 63: 341-367. 
JUDGE, T. A., WOOLF, E. F., \& HURST, C. (2009). "Is Emotional Labor More Difficult For Some Than For Others? A Multilevel, Experience-Sampling Study", Personnel Psychology, 62(1): 57-88.

KATH, L. M., STICHLER, J. F., \& EHRHART, M. G. (2012). "Moderators of the negative outcomes of nurse manager stress", Journal of Nursing Administration, 42(4): 215 221.

KAUPPILA, O. P. (2016). "When and how does LMX differentiation influence followers' work outcomes? The interactive roles of one's own LMX status and organizational context", Personnel Psychology, 69(2): 357-393.

KRISTOF, A. L. (1996). "Person-organization fit: An integrative review of its conceptualizations, measurement, and implications", Personnel Psychology, 49(1):149.

KRISTOF-BROWN, A. L., ZIMMERMAN, R. D., \& JOHNSON, E. C. (2005). "Consequences of Individuals'fit At Work: A Meta-Analysis of Person-Job, PersonOrganization, Person-Group, And Person-Supervisor Fit”, Personnel Psychology, 58(2): 281-342.

KWAK, C., CHUNG, B. Y., XU, Y. \& EUN-JUNG, C. (2010). "Relationship of job satisfaction with perceived organizational support and quality of care among South Korean nurses: A questionnaire survey", International Journal of Nursing Studies, 47(10): 1292-1298.

LASCHINGER, H. K. S., WONG, C. A., \& GRECO, P. (2006). "The impact of staff nurse empowerment on person-job fit and work engagement/burnout", Nursing Administration Quarterly, 30(4): 358-367.

LIAO, H. \& CHUANG, A. (2007). "Transforming service employees and climate: a multilevel, multisource examination of transformational leadership in building longterm service relationships", The Journal of Applied Psychology, 92(4): 1006-1019.

MEYER, J. P. HECHT, T. D., GILL, H., \& TOPLONYTSKY, L. (2010). "Personorganization (culture) fit and employee commitment under conditions of organizational change: A longitudinal study" , Journal of Vocational Behavior,76(3): 458-473.

MONEKE, N., \& UMEH, O. J. (2015). "Factors Influencing Critical Care Nurses' Perception of Their Overall Job Satisfaction: An Empirical Study", The Journal of Nursing Administration, 45(10): 45-51.

MOURA, D., ORGAMBÍDEZ-RAMOS, A., \& GONÇALVES, G. (2014). "Role stress and work engagement as antecedents of job satisfaction: Results from Portugal”, Europe's Journal of Psychology, 10(2): 291-300.

NETEMEYER, R. G., BOLES, J. S., MCKEE, D. O., \& MCMURRIAN, R. (1997). “An investigation into the antecedents of organizational citizenship behaviors in a personal selling context", Journal of Marketing, 61(3): 85-98.

ORGAMBÍDEZ-RAMOS, A., BORREGO-ALÉS, Y., \& MENDOZA-SİERRA, I. (2014). "Role stress and work engagement as antecedents of job satisfaction in Spanish workers", Journal of Industrial Engineering and Management, 7(1): 360-372. 
PODSAKOFF, P. M., MACKENZIE, S. B., \& BOMMER, W. H. (1996). “Transformational leader behaviors and substitutes for leadership as determinants of employee satisfaction, commitment, trust, and organizational citizenship behaviors", Journal of Management, 22(2): 259-298.

POHL, S., \& GALLETTA, M. (2017). "The role of supervisor emotional support on individual job satisfaction: A multilevel analysis", Applied Nursing Research, 33: 6166.

RAFFERTY A, CLARKE SP, COLES J, BALL D, JAMES P, McKEE M, et al. (2007). Outcomes of variation in hospital nurse staffing in English hospitals: cross-sectional analysis of survey data and discharge records. Int J Nurs Stud, 44:175-82.

RISMAN, K. L. ERICKSON, R. J. \& DIEFENDORFF, J. M. (2016). "The impact of personorganization fit on nurse job satisfaction and patient care quality" , Applied Nursing Research, 31: 121-125. doi: 10.1016/j.apnr.2016.01.007

SCHNEIDER, B., GOLDSTIEIN, H. W., \& SMITH, D. B. (1995). "The ASA framework: An update", Personnel Psychology, 48(4): 747-773.

SEKARAN, U. (1992). Research methods for business, Canada, John Wiley and Sons, Inc.

SEO, Y., KO, J., \& PRICE, J. L. (2004). "The determinants of job satisfaction among hospital nurses: a model estimation in Korea", International Journal of Nursing Studies, 41(4): 437-446.

SONG, Z., \& CHATHOTH, P. K. (2011). “Intern newcomers' global self-esteem, overall job satisfaction, and choice intention: Person-organization fit as a mediator", International Journal of Hospitality Management, 30(1): 119-128.

TOTTERDELL, P. \& HOLMAN D. (1998). "Emotion Regulation in Customer Service Roles: Testing A Model Of Emotional Labor", Journal of Personality and Social Psychology, 74(6), 115.

TOURANGEAU, A. N. N., CRANLEY, L., S. L, H. K., \& PACHİS, J. (2010). “ Relationships among leadership practices, work environments, staff communication and outcomes in long-term care", Journal of Nursing Management, 18(8):1060-1072.

TURUNÇ, Ö., TÜRKÖZ, T., AKKOÇ, İ., \& ÇALIŞKAN, A. (2013). "How do innovative and entrepreneurial behaviours affect the job performance?: The moderating role of person-organisation fit. International Journal Business Innovation and Research, 7(5): 590-618.

VERPLANKEN, B. (2004). "Value congruence and job satisfaction among nurses: a human relations perspective", International Journal of Nursing Studies, 41(6): 599-605.

VILELA, B. B., GONZÁLEZ, J. A. V., \& FERRIN, P. F. (2008). "Person-organization fit, OCB and performance appraisal: Evidence from matched supervisor-salesperson data set in a Spanish context", Industrial Marketing Management, 37(8): 1005-1019.

ZHANG, M., YAN, F., WANG, W., \& Lİ, G. (2017). "Is the effect of person-organisation fit on turnover intention mediated by job satisfaction? A survey of community health workers in China", BMJ open, 7(2): 1-8. 